\title{
John Locke on Respiration
}

\author{
JONATHAN WALMSLEY*
}

\section{Introduction}

During the early part of his career as an academic in 1660s Oxford, John Locke trained as a physician. ${ }^{1}$ Acquainted with some of the most brilliant researchers of his dayRobert Boyle, Thomas Willis, Richard Lower and Robert Hooke-and an active member of the scientific community, Locke was part of a generation that revolutionized natural philosophy. He never published a natural philosophical work, but in the extant manuscripts from this period there is evidence that he was deeply concerned with the subject of respiration and avidly pursued this interest in collaboration with his more distinguished contemporaries.

Locke's work in this field has been treated by both Kenneth Dewhurst and Robert G Frank. There are, however, good reasons for re-visiting this subject. Dewhurst's transcription of 'Respirationis usus', Locke's major essay on this topic, was inexact. ${ }^{2}$ Whilst a prolific and enlightening scholar, Dewhurst's research was inaccurate in several important matters of fact and interpretation, muddling the chronology of Locke's work and erroneously attributing scholastic theories to 'Respirationis usus'. ${ }^{3}$ Frank in Harvey and the Oxford physiologists provides a superb account of the origins of modern

(C) Jonathan Walmsley 2007

*J C Walmsley, AKQA, 175 Varick Street, New York, NY 10014, USA.

I would like to thank the British Academy for the funding that made the writing of this paper possible. I am grateful to Dr J R Milton for the extensive assistance he has provided in reviewing and commenting on several versions of this paper. Thanks are also due to Dr Paul Schuurman and the anonymous referees for their helpful comments and suggestions. Finally, I would also like to thank Ellen Meyer and Gus Kenyon for their help with the translation of Locke's Latin. All errors are my own.

${ }^{1} \mathrm{~J}$ R Milton, 'Locke at Oxford', in G A J Rogers (ed.), Locke's philosophy: content and context, Oxford University Press, 1994, pp. 29-47.

${ }^{2}$ National Archives, Kew (hereafter NA) PRO 30/24/47/2, fols. 71-74. Printed in K Dewhurst, 'Locke's essay on respiration', Bull. Hist. Med., 1960, 24: 257-73. Milton, op. cit., note 1 above, p. 33, n. 13 , points out that the present binding of the papers in the Shaftesbury collection has the middle piece of paper bound in back-to-front. Dewhurst's transcription in following the text as it has been bound, not as it was written, completely obscures the structure of the article as intended by Locke. Additionally, Dewhurst makes numerous errors of transcription.

${ }^{3} \mathrm{~K}$ Dewhurst, 'Locke's contribution to Boyle's researches on the air and on human blood', Notes and Records of the Royal Society of London, 1962, 17: 198-206, and idem, John Locke, 1632-1704, physician and philosopher, London, Wellcome Historical Medical Library, 1963, on pp. 12-17. Detailed corrections of dating are presented below. Dewhurst characterized 'Respirationis usus' as follows: "It is not a good essay as [Locke] neglected to support his theories with experimental evidence, and included many out-dated ideas of the classical physicians, together with Swammerdam's notion of respiration serving to cool the blood" (Dewhurst, John Locke, p. 15). This is surprising since in his previous paper he had stated that Locke's theory "is opposite to the teaching of Galen" (Dewhurst, 'Locke's essay', op. cit., note 2 above, p. 265 , n. 31 ). 


\section{Jonathan Walmsley}

physiology, weaving together the work of numerous thinkers across several decades. ${ }^{4}$ Whilst much more accurate than Dewhurst, Frank did not furnish a revised version of 'Respirationis usus'. 5 In presenting the views of different thinkers as part of a larger research project, Frank did not always highlight the contrasts of opinion between researchers as perhaps he could have, and the subtleties of Locke's position get somewhat lost amongst the work of his contemporaries. For example, Frank cuts short some of Locke's notes so that the supporting material presented for his claims is omitted, tending to obscure the differences between Locke's conclusions and those of his colleagues. ${ }^{6}$

Since the completion of Dewhurst's and Frank's work, new light has been shed on Locke's natural philosophical career. Analyses of his commonplacing method have facilitated the creation of a much more accurate chronology of his reading, note-taking and experimentation. ${ }^{7}$ A survey of his commonplace books has also revealed several new notes on the subject of respiration. ${ }^{8}$ In addition, a new transcription and translation of 'Respirationis usus' has been prepared in the writing of this paper. Finally, scholars have recently put forward significant new interpretations of both Locke's and Boyle's natural philosophical views. Locke's relationship with Boyle in the 1660s, and its subsequent impact on the Essay concerning human understanding, has long interested intellectual historians. Historians of philosophy have generally supposed that Locke directly adopted Boyle's mechanical philosophy as a result of their collaboration in this period. ${ }^{9}$ Historians of science and medicine have recently sought to portray Boyle's own adherence to the mechanical philosophy as more complex than previously supposed. ${ }^{10}$ Simultaneously, research on Locke's medical outlook in the mid-1660s shows him to have been sceptical of Boyle's views on a number of important issues related to mechanism. ${ }^{11}$ Locke's work on respiration provides further detail on his natural philosophical outlook and on his relationship with Boyle at this time. Further, it provides a stimulating snapshot of the rapid, fluid and complex forces at work in the "scientific revolution", by someone who would become one of the period's most eminent men.

\footnotetext{
${ }^{4} \mathrm{R}$ G Frank, Harvey and the Oxford physiologists, Berkeley, University of California Press, 1980.

${ }^{5}$ The kernel of Frank's treatment of Locke is presented in Frank, op. cit., note 4 above, pp. 186-8, 195-6.

${ }^{6}$ For example, Frank omits Locke's reference to J B van Helmont from the note Locke made on "Sanguis" (Bodleian Library (hereafter Bodl.) MS Locke f.19, p. 227, cf. Frank, op. cit., note 4 above, pp. 187-8), and omits the following note on "Sal Volatile" which again references Helmont in connection with the volatization due to air (Bodl. MS Locke f.19, pp. 227, 272).

${ }^{7}$ See J R Milton, 'The date and significance of two of Locke's early manuscripts', Locke Newsletter, 1988, 19: 47-89, and J C Walmsley and J R Milton, 'Locke's notebook "Adversaria 4" and his early training in chemistry', Locke Newsletter, 1999, 30: $85-191$.
}

\footnotetext{
${ }^{8}$ Previously unpublished notes will be indicated in their respective footnotes.

${ }^{9}$ Variations on this theme have appeared in R I Aaron, John Locke, Oxford University Press, 1937; P Alexander, Ideas, qualities and corpuscles, Cambridge University Press, 1985; and E McCann, 'Locke's philosophy of body', in V Chappell (ed.), The Cambridge companion to Locke, Cambridge University Press, 1994, pp. 56-88.

${ }^{10}$ See, for example, A Clericuzio, 'A redefinition of Boyle's chemistry and corpuscular philosophy', Ann. Sci., 1990, 47: 561-89, on pp. 573-9, and L M Principe, The aspiring adept: Robert Boyle and his alchemical quest, Princeton University Press, 1998.

${ }^{11}$ See J Walmsley, 'Morbus: Locke's early essay on disease', Early Sci. Med., 2000, 5: 366-93, and J Walmsley, "“Morbus," Locke and Boyle: a response to Peter Anstey', Early Sci. Med., 2002, 7: 378-97.
} 


\section{John Locke on Respiration}

\section{Locke's Physiological Studies}

John Locke had a long-standing interest in medicine. One of his earliest medical notes, from the late 1650s, confirmed Harvey's discovery of the circulation of the blood: "Circulatio Sanguinis Take a frog \& strip it you may see $\mathrm{y}^{\mathrm{e}}$ circulation of bloud if you hold him up ag ${ }^{\mathrm{t}} \mathrm{y}^{\mathrm{e}}$ sun." "12 Harvey's result undermined Galenic theory and revolutionized the study of physiology. Locke studied the writings of several Galenic physicians, Daniel Sennert in particular. ${ }^{13}$ Though an innovator within the Galenic tradition, holding that bodies were collections of atoms composed of the four elements and subject to overarching forms, ${ }^{14}$ Sennert presented a traditional explanation for respiration. For Sennert, in his Institutionum medicinae, there were three faculties of the soul. ${ }^{15}$ The first was the natural faculty which nourished the body by the natural spirits. The liver, the seat of this faculty, created the nutritive blood from chyle passed from the stomach, and distributed it via the veins. The vital faculty concerned the heart, the lungs, respiration and the pulse:

The Vital Spirit is generated in the heart, of the thinnest and purest blood, or the natural Spirit, commonly so called, and aêr, by help of respiration drawn, and by the dilatation of the Arteries in the left Ventricle of the heart, and being there freed from all fuliginous vapours is distributed through the Arteries into all the parts of the body ... Now this Spirit with its innate heat in the heart, is not onely the chief instrument of the actions of the heart, but is distributed through the Arteries into the whole body, and stirreth up, cherisheth, increaseth, and strengthneth the innate heat in all the parts ... ${ }^{16}$

Air provided material for the creation of the vital spirits to be distributed by the arterial blood. It was also supposed to cool the native heat of the heart, expelling the warm waste vapours produced in the making of the vital spirits: "by expiration the Lungs and Breast being contracted, the hotter air and fuliginous vapours are sent forth at the mouth and nostrils". ${ }^{17}$ The veins and the arteries were independent; the one serving the natural faculty, the other, the vital. The only contact between the two systems was at the heart, where venous blood was supposed to pass directly from the right to the left ventricle, to create the vital spirits in tandem with the air. Animal spirits were produced in the brain, distributed around the body by nerves and regulated consciousness, movement and awareness. ${ }^{18}$ Each of the three faculties, natural, vital, and animal had its own origin, effector vessels and active spirit. One virtue of Galenism was its systematic nature. ${ }^{19}$

\footnotetext{
${ }^{12}$ Bodl. MS Locke e.4, p. 111.

${ }^{13}$ There were 196 entries made on Sennert in Bodl. MS Locke f.18, sixty-nine in Bodl. MS Locke d.11, two in Bodl. MS Locke d.9, and about thirty-one entries in Bodl. MS Locke f.21. See G G Meynell, 'A database for John Locke's medical notebooks and medical reading', Med. Hist., 1997, 41: 473-86, on p. 483 , Table 3 .

${ }^{14}$ For a discussion of Sennert's thought and his marriage of alchemical corpuscularianism and Galenic doctrine, see W R Newman, 'The alchemical sources of Robert Boyle's corpuscular philosophy', Ann. Sci., 1996, 53: 567-85, on pp. 573-6.
}

\footnotetext{
${ }^{15}$ Sennert's Institutionum medicinae was first published in 1611, but Locke made a detailed study of it as part of Sennert's Opera omnia, Lyons, Joannis Antonii Huguetan, \& Marci Antonii Ravaud, 1654-1656. Quotations derive from the first English translation: The institutions or fundamentals of the whole art, both of physick and chirurgery, divided into five books, London, L Lloyd, 1656.

${ }^{16}$ Ibid., bk 1, ch. vi, p. 13.

${ }^{17}$ Ibid., bk 1, ch. xi, p. 25.

${ }^{18}$ Ibid., bk 1, ch. vi, p. 13.

${ }^{19}$ For more detail, see Frank, op. cit., note 4 above, pp. 2-9.
} 


\section{Jonathan Walmsley}

Galenic orthodoxy was already under attack from the "Chymical" school founded by Paracelsus. ${ }^{20}$ At the time of Locke's interest in the subject, J B van Helmont was the most influential writer in this tradition. ${ }^{21}$ Helmont's vitalistic theories centred on active "ferments" in nature responsible for the "chymical" combination and transformation of bodies. Though probably aware of Harvey's discovery of the circulation of the blood, Helmont built his physiology around the traditional Galenic systems of veins and arteries meeting at the heart. ${ }^{22} \mathrm{He}$ maintained that air helped chemically dissolve venous blood: "the whole Venal bloud, that it may depart into a Gas, it hath need of two wings to fly, the aire and a ferment". ${ }^{23}$ In exposure to the air, the sulphur of the blood was carried away, leaving the salt without anything to "fix" upon, rendering the blood volatile:

If the Air (let him who can, comprehend the secret) doth in the first place, volatize the Sulphur of the composed Body, with the every way separation of its Salt, this Salt (which else in the Coal, should be fixed into an Alkali, by the fire) is made wholly volatile $\ldots{ }^{24}$

This was the purpose of respiration: "it is manifest, that from a continual necessity, the Air is drawn inward for a peculiar end, that it may cause the bloud of the veins ... to be plainly volatile". ${ }^{25}$ The volatile venous blood was then transformed by a ferment in the left ventricle:

Indeed, in the left bosom of the heart, as it were in a stomach, doth a singular, most vitall, and lightsom Ferment dwell, which is a sufficient cause of the venall bloud its being transchanged into arterial bloud, even as it is chief in the transmutation of arteriall bloud into vitall Spirit. ${ }^{26}$

Locke made a detailed study of Helmont's work. ${ }^{27}$

The discovery of the blood's circulation only added to the difficulties besetting traditional medical theory and made physiology one of the most interesting research projects of the time. Why did the blood circulate? Why must it pass through the lungs? What role did the air play with respect to the blood? What role the heart? Locke's interest could not have been piqued at a more propitious time, since his contemporaries were engaged in detailed research on just these questions. Robert Boyle, for example, was completing the experimental work he would publish in the New experiments physico-mechanicall, touching the spring of the air, and its effects. ${ }^{28}$ Boyle, with Hooke's assistance, used an air pump to show how the air's physical properties could affect respiration. In Experiments 10-12,

\footnotetext{
20 "Chymistry" is used in the broad seventeenthcentury meaning of the term, see W R Newman and L M Principe, 'Alchemy vs. chemistry: the etymological origins of a historiographic mistake', Early Sci. Med., 1998, 3: 32-65.

${ }^{21}$ The standard reference on Helmont is W Pagel, Joan Baptista van Helmont, Cambridge University Press, 1982.

${ }^{22}$ For Helmont's physiology, see Pagel, op. cit., note 21 above, pp. 88-92.

${ }^{23} \mathrm{~J}$ B van Helmont, Oriatrike or, Physick refined, London, Lodowick Loyd, 1662, p. 182.

${ }^{24}$ Ibid., p. 184.

${ }^{25}$ Ibid.

${ }^{26}$ Ibid., p. 179.
}

\footnotetext{
${ }^{27}$ For Locke's study of the 1648 edition of Helmont's Ortus medicinae c. 1660-1, see British Library (hereafter BL) Add. MS 32554, fol. 42r, and of the 1652 edition at points between 1665 and 1667, see Bodl. MS Locke f.22, p. 109. Cf. other references in Bodl. MSS Locke f.14, d.9, d.11, f.25, and Locke's Memorandum book for 1667, Bodl. MS Film 79. Locke also made notes in his copy of the 1652 edition (J Harrison and P Laslett, The library of John Locke, Oxford University Press, 1971 (hereafter H\&L), item 1417, Appendix IIC, p. 282)

${ }^{28} \mathrm{R}$ Boyle, New experiments physicomechanicall, touching the spring of the air, and its effects, Oxford, H Hall, for T Robinson, 1660.
} 


\section{John Locke on Respiration}

Boyle connected fresh air and combustion. ${ }^{29}$ In Experiments 40 and 41, he noted that animals placed in a vacuum would die "from the want of Air". ${ }^{30}$ In "A Digression containing some Doubts touching Respiration', Boyle dismissed Galenic “cooling” explanations of this phenomenon, ${ }^{31}$ and presented two possible alternatives. First, that

the Air does not onely, as a Receptacle, admit into its Pores the Excrementitious vapors of the Blood, when they are expell'd through the Wind-Pipe, but does also convey them out of the Lungs, in regard that the inspired Air, reaching to all the ends of the Aspera Arteria, does there associate it self with the Exhalations of the circulating Blood, and when 'tis exploded, carrys them away with it self ... 32

A shortage of air particles would mean that the vapours could not be carried off. Boyle found this theory "congruous enough" to his observations, and noted the fainting of miners where "the Air too much thicken'd (and as it were clogg'd) with Steams, is unfit for Respiration". 33 One possible explanation in place, Boyle mentioned a second:

Paracelsus indeed tells us, That... the Lungs consume part of the Air, and proscribe the rest. So that according to our Hermetick Philosopher ... it seems we may suppose, that there is in the Air a little vital Quintessence ... which serves to the refreshment and restauration of our vital Spirits, for which use the grosser and incomparably greater part of the Air being unserviceable, it need not seem strange that an Animal stands in need of almost incessantly drawing in fresh Air. ${ }^{34}$

The theory that the air was used to produce vital spirits was common to the Galenic and Paracelsian traditions. Despite this, Boyle was not impressed:

this Opinion is not ... absurd, yet besides that, it should not be barely asserted, but explicated and prov'd; and besides that, some Objections may be fram'd against it, out of what has been already argu'd against the Transmutation of Air into vital Spirits: Besides these things, it seems not probable, that the bare want of the Generation of the wonted quantity of vital Spirits, for less then one minute, should within that time be able to kill a lively Animal ... 35

Boyle had wide-ranging interests in the "chymistry" of his day, but in this particular, it appears that he did not suppose that the purpose of respiration was to draw in something from the air. ${ }^{36}$ It may well be that his experiments' emphasis on the physical properties of the air coloured his views on this subject. Locke read this work and soon made the author's acquaintance. $^{37}$

Locke continued to read Boyle's works as soon as they were published, turning next to the Certain physiological essays, containing significant research on the properties of niter. ${ }^{38}$ Niter was a topic of considerable contemporary interest because of its notable

\footnotetext{
${ }^{29} \mathrm{R}$ Boyle, The works of Robert Boyle, ed. M Hunter and E B Davis, 10 vols, London, Pickering \& Chatto, 1999-2000, vol. 1, pp. 184-8.

${ }^{30}$ Ibid., pp. 273-6, quote on p. 275.

${ }^{31}$ Ibid., pp. 276-95, quote on pp. 281-2.

${ }^{32}$ Ibid., p. 283.

${ }^{33}$ Ibid.

${ }^{34}$ Ibid., p. 287.

${ }^{35}$ Ibid.

${ }^{36}$ For further detail on Boyle's New experiments, see Frank, op. cit., note 4 above, pp. 142-8.
}

\footnotetext{
${ }^{37}$ See for example, notes on "Aer" and "Aqua" in BL Add. MS 32554, fol. 9r and fol. 20r, respectively. John Locke, The correspondence of John Locke, ed. E S de Beer, 9 vols, Oxford University Press, 1976- (hereafter Corr.), Letter 97, vol. 1, pp. 146-7.

${ }^{38} \mathrm{R}$ Boyle, Certain physiological essays, written at distant times, and on several occasions, London, Henry Herringman, 1661. See Bodl. MS Locke f.14, pp. 22-3.
} 


\section{Jonathan Walmsley}

chemical properties. In particular, there was much speculation amongst the "chymists" that niter might be the active agent in the air, and that respiration served to draw this in to sustain physiological processes. ${ }^{39}$ Locke read George Ent's defence of Harvey's work, ${ }^{40}$ the Apologia pro circulatione sanguinis, which argued that air was necessary to feed a "vital flame" in the heart, since it contained niter, and niter was a necessary element of combustion. ${ }^{41}$ This "chymical" tradition was widely studied in Oxford at the time of Locke's researches, and found further expression in Thomas Willis's Diatribae duae. ${ }^{42}$ Willis believed the blood to be a heterogeneous liquid with parts of salt, sulphur and spirit. He supposed a "nitrosulphurous" ferment in the heart's left ventricle which loosened the bonds of the particles and allowed the sulphurous particles to escape, thus causing an "ascension" or "effervescence" in the blood. This heated the blood and altered its colour. The fermented blood was then distributed throughout the body to heat it. Willis hinted that "nitrosulphurous" particles of air fed this "flamma vitalis". ${ }^{43}$ Locke took notes upon both parts of this book. ${ }^{44}$

Up to date with both physical and chemical explanations, Locke was fully abreast of contemporary theories concerning the nature and purpose of respiration. His own views cannot be determined by the texts he consulted. However, one early note is revealing: "Respiratio of its cause and purpose. Ent: p.96. Boyl. op: ex: 40.41."45 Locke was apparently content to countenance either the physical explanation favoured by Boyle or the chemical account of Ent-here referring directly to Experiments 40 and 41 of Boyle's New experiments, and the theory proposed in Ent's Apologia. In the early part of the 1660s Locke had read a great deal, but had contributed little to the debate. He was well aware of the competing explanations and seems to have favoured the work of the "moderns" over the Galenists, but does not appear to have had his own investigative agenda, experimental interests, or convictions about the direction of future research on the subject.

\section{Locke and Lower}

In June 1664 Richard Lower wrote to Robert Boyle concerning some physiological problems he was then grappling with, specifically: "the reason of the different colour of the blood of the veins and arteries: the one being florid and purple red, the other dark and blackish". ${ }^{46}$ Both had been working on related issues for several years and both were known to Locke-Lower in particular, since the two men had virtually parallel careers.

\footnotetext{
${ }^{39}$ Frank, op. cit., note 4 above, pp. 121-8.

${ }^{40}$ Ent's views are discussed in Frank, op. cit., note 4 above, pp. 22-5, 106-13.

${ }^{41} \mathrm{G}$ Ent, Apologia pro circulatione sanguinis, London, Young \& Hope, 1641. Cf. Bodl. MS Locke f.20, p. 174, and listed in the index on p. 265. For the dating of this MS, see J R Milton, 'John Locke's medical notebooks', Locke Newsletter, 1997, 28: 135-56, on p. 142. On niter, see Frank, op. cit., note 4 above, pp. 110-11.

${ }^{42}$ T Willis, Diatriba duce medico-philosophica, London, Martin, Allestry, \& Dicas, 1660.

${ }^{43}$ Frank, op. cit., note 4 above, pp. 167-9.
}

\footnotetext{
${ }^{44}$ The two halves being De fermentatione (Bodl. MS Locke e.4, pp. 97-104) and De febribus (Bodl. MS Locke d.11, fols. 91v, 270r-269v rev., cf. Bodl. MS Locke c.29, fols. 11v-12r, $17 \mathrm{v}-18 \mathrm{r})$.

45 "Respiratio ejus causa et finis. Ent: p.96. Boyl. op: ex: 40.41.”, Bodl. MS Locke d.11, fol. 73v. Not previously published.

${ }^{46}$ Letter from Richard Lower to Robert Boyle, 24 Jun. 1664, in R Boyle, The correspondence of Robert Boyle, ed. M Hunter, A Clericuzio and L M Principe, 6 vols, London, Pickering \& Chatto, 2001, vol. 2, p. 288.
} 


\section{John Locke on Respiration}

Lower came to Oxford from Westminster in 1649, three years before Locke, acquiring a Studentship at Christ Church, as Locke would three years later. Lower was a lecturer in Greek from 1656 to 1657 and was a censor in natural philosophy from 1657 to 1660; Locke was lecturer in Greek from 1660 to 1662 , lecturer in rhetoric in 1663 , and censor in $1664 .^{47}$ Both attended Willis's 1662 lectures as Sedleian professor of natural philosophy. ${ }^{48}$ Both attended chymistry lessons given by Peter Stahl. ${ }^{49}$

When Lower recommenced his research on respiration and the blood in 1664, Locke appears to have become his collaborator. Locke's notes, previously detailing only his reading, now began to focus on experimental research, often citing Lower as a source for some new finding. Their initial area of interest seems to have been the physical process of breathing. In a memorandum book begun in 1664, Locke recorded a recent result:

Respiratio Open a hole in each side of a dog and cut off the nerves that go to the diaphragm, the dog will die immediately. But if you cut off the eight pair that go to the lungs he will live two or three days. Bloud will be congealed in the vessells

JL Mr Lower. ${ }^{50}$

Locke appended his initials to those notes he originated, so their appearance alongside Lower's name suggests this experiment was a joint effort. Lower was at the forefront of physiological research at the time-this result helping to demonstrate that the diaphragm was the active agent of inspiration.

Such hands-on research activities, coupled with his extensive study, prompted Locke to undertake further theoretical explorations on the subject, and it was not long before he formulated his first treatment of the purpose of respiration:

Respiratio One use of respiration seems to be for $\mathrm{y}^{\mathrm{e}}$ carrying away those vaparous excrement of $\mathrm{y}^{\mathrm{e}}$ bloud $\mathrm{w}^{\mathrm{c}}$ are usually cald fuliginos, $\mathrm{w}^{\mathrm{ch}}$ findeing a fit receptacle in $\mathrm{y}^{\mathrm{e}}$ pores of $\mathrm{y}^{\mathrm{e}}$ aire drawne into $y^{\mathrm{e}}$ lungs insinuate them selves \& soe are cast out in expiration $\& \mathrm{y}^{\mathrm{e}}$ bloud ventilatd, but if the pores of $\mathrm{y}^{\mathrm{e}}$ aire be allready fild with steams soe as not to be able to receive those effluvia it is not fit for respiration \& hence it probably comes $\mathrm{y}^{\mathrm{t}}$ in crowds people swoune, adde to this what Dr Power in his Experimental Philosophy p.179. $\underline{64}^{51}$ observes of Damps in Cole mines, $\mathrm{y}^{\mathrm{t}} \mathrm{y}^{\mathrm{e}}$ effluvium $\mathrm{y}^{\mathrm{t}}$ come out of their owne bodys espetially when they sweat will cause them \& put out their candles, $w^{\text {ch }}$ will burne longer neare $y^{\mathrm{e}}$ floore then roofe of there lanes, $\mathrm{y}^{\mathrm{e}}$ damp runing along $\mathrm{y}^{\mathrm{e}}$ roofe. JL. Another use of respiration seems to be to mixe some particles of aier with $\mathrm{y}^{\mathrm{e}}$ bloud \& soe to volatize it, since it appears $\mathrm{y}^{\mathrm{t}}$ vegitable substances neither ferment nor yield any volatile salt without a communication with $\mathrm{y}^{\mathrm{e}}$ open aier, for noe vegitable distild in close vessels affords any volatile salt but, vegitables burnt in $\mathrm{y}^{\mathrm{e}}$ open aier, \& soe mixing its volatile parts with those of $\mathrm{y}^{\mathrm{e}}$ aire is turnd into soot $\mathrm{w}^{\mathrm{ch}}$ being distild in close vessels yields a volatile salt very little differing from $\mathrm{y}^{\mathrm{t}}$ of Bloud or Harts horne. JL. \& hence possibly is $\mathrm{y}^{\mathrm{e}}$ reason why charcoale kept in a glasse exactly stopd will

\footnotetext{
${ }^{47}$ Milton, op. cit., note 1 above, p. 32.

${ }^{48} \mathrm{~T}$ Willis, Thomas Wills's Oxford lectures, ed. K Dewhurst, Oxford, Sandford Publications, 1980.

${ }^{49}$ Locke in 1663 , Lower at some point between 1659 and 1662. See A Clark (ed.), The life and times of Anthony Wood, 1632-1695, 5 vols, Oxford

Historical Society at the Clarendon Press, 1891-1900, vol. 1, pp. 472-3.

${ }^{50}$ Bodl. MS Locke f.27, p. 13a, cf. Bodl. MS Locke f.19, p. 158.
}

\begin{abstract}
${ }^{51}$ Henry Power, Experimental philosophy, in three books: containing new experiments microscopical, mercurial, magnetical, London, Martin \& Allestry, 1664. Power's Experimental philosophy was the first English publication on microscopy, preceding Hooke's Micrographia by a year, containing several observations on the air, spontaneous generation and the numerous other phenomena under discussion by the early Royal Society. The standard reference is C Webster, 'Henry Power's experimental philosophy', Ambix, 1967, 14: 150-78.
\end{abstract}




\section{Jonathan Walmsley}

never calcine to ashes in the greatest fire because no aire comes to mix with it $\&$ make any of $\mathrm{y}^{\mathrm{e}}$ parts volatile .v. Boyle. Scept. Chym. p.62. 61

Cut a hole in each side of a dog. ${ }^{52}$

Locke asserted first that a "vaparous excrement" was fitted on to the "pores of $y^{\mathrm{e}}$ aire drawne into y lungs" and then expelled from the body through exhalation. This theory, Locke held, was supported by the collapsing of people in crowded rooms and the fainting of miners, where, it was supposed, the air became saturated with this excrement. Echoing the results and conclusions of Boyle's New experiments, Locke appended this theory with his initials "JL" implying the end of the note on this particular subject.

But he evidently felt that this was not a comprehensive explanation. Similar to his earlier note on the cause and purpose of respiration, Locke went on to juxtapose this physical theory with a chymical explanation. Locke continued by supposing further that parts of the air mixed with the blood, volitizing it and making it more reactive. He was motivated by chymical findings concerning the role of air in fermentation and volatility. For example, vegetables would not burn, distil or ferment without air. Equally, charcoal heated in the open air would turn to ash, but would not in a closed vessel. ${ }^{53}$ Locke referred to Boyle's Sceptical chymist to support this conjecture, but was not citing Boyle's own research-as Boyle recorded in the text cited, the "Experiment is that of Helmont". ${ }^{54}$ Locke noted the role of the air in the creation of soot and other chemical reactions:

Fuligo Soot seems not to be generated but from things burnt in $\mathrm{y}^{\mathrm{e}}$ common aire, \& therefor $\mathrm{y}^{\mathrm{e}}$ parts sublimated by $\mathrm{y}^{\mathrm{e}}$ fire may be well supposed to unite them selves with some particles of $\mathrm{y}^{\mathrm{e}}$ aer or else some salt or other matter flying about in it. from which union is generated $\mathrm{y}^{\mathrm{t}}$ body we call soot. v. Boyle. Scept. Chym. p.49: 61. JL.

Consider too $\mathrm{y}^{\mathrm{e}}$ difference of fire workeing upon Sulphur in close vessells \& $\mathrm{y}^{\mathrm{e}}$ open aier, in one it produces only flowers in $\mathrm{y}^{\mathrm{e}}$ other an acid liquor $\mathrm{JL}^{55}$

In the passage Locke cited, Boyle noted similar results, simultaneously drawing attention to the "Helmontian expression" of these findings. ${ }^{56}$ Such experimental discoveries were leading Locke to consider a chymical component to the process and purpose of respiration.

Locke now began to focus his attention on practical findings concerning the volatility of salts, fermentation and the air. For example, in an extended note entitled "Sal Volatile", ${ }^{57}$ Locke noted that fermentation caused volatility: "things fermented yeild a great deale of volatile $\mathrm{sp}^{\mathrm{t}}$, but I suppose noe oyle. \& lesse alkali then otherwise they would do unfermented." 58 He then tried to pinpoint the connection between fermentation and volatility:

liquors without fermentation yeild noe $\mathrm{sp}^{\mathrm{t}}$ or volatile salts, but animall substances doe because they are fermented in $\mathrm{y}^{\mathrm{e}}$ bodys of $\mathrm{y}^{\mathrm{e}}$ liveing animalls. v. Boyle Scept. Chym. p.231. \& hence perhaps is

\footnotetext{
${ }^{52}$ BL Add. MS 32554, fols. 48r, 49r. Not previously published in full. The last sentence, "Cut a hole in each side of a dog", was apparently copied from the note in Locke's memorandum book, suggesting this speculation was later than the first note.

${ }^{53}$ Boyle, op. cit., note 29 above, vol. 2, pp. 238-9.
}

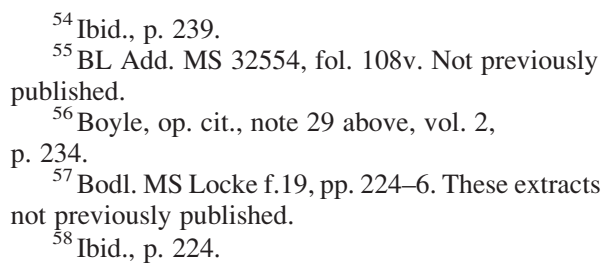




\section{John Locke on Respiration}

$y^{\mathrm{e}}$ reason why fat $\&$ oleaginous substances are with soe much difficulty if at all fermented: because of $\mathrm{y}^{\mathrm{e}}$ want of salt $\mathrm{w}^{\mathrm{ch}}$ is $\mathrm{y}^{\mathrm{e}}$ cause \& a necessary ingredient of fermentation. ${ }^{59}$

Locke postulated that a salt was a pre-requisite of any fermentation. It is notable that, once again, this reference to Boyle was in fact an indirect reference to an experiment of "Helmont", where salt may be produced from spirit of wine. ${ }^{60}$ Locke then noted:

what interest $\mathrm{y}^{\mathrm{e}}$ aer hath in this businesse of fermentation will be worth enquiry. since noe fermentation is without a communication $\mathrm{w}^{\text {th }} \mathrm{y}^{\mathrm{e}}$ aier, nor will soot (out of $\mathrm{w}^{\text {ch }}$ may be distild a volatile salt like $\mathrm{y}^{\mathrm{t}}$ of animal substances) be generated in close vessels out of $\mathrm{w}^{\mathrm{ch}} \mathrm{y}^{\mathrm{e}}$ aire is excluded JL v. Boyle. Scept: Chym. p. 267. $\underline{61}^{61}$

Air was a pre-requisite of fermentation and volatility. The distillation of soot appeared to suggest that air itself may be able to supply the salt necessary to create the volatilitywithout air neither the soot, nor its volatile salt, was created. Something in the air, perhaps some "salt", played the crucial role in volatizing bodies, explaining why "noe fermentation is without a communication $w^{\text {th }} \mathrm{y}^{\mathrm{e}}$ aier". ${ }^{62}$

These chymical speculations informed Locke's reflections on the difficulties of breathing at altitude, as recorded in his memorandum book:

Respiratio whether $\mathrm{y}^{\mathrm{e}}$ aer, as we are told by travellers on pike Tenerif \& $\mathrm{y}^{\mathrm{e}}$ Andes in peru \& other great heights, be lesse usefull to respiration, because of any extraordinary quality, or $\mathrm{y}^{\mathrm{t}}$ it wants some of those salts or other materiall parts $\mathrm{w}^{\mathrm{ch}}$ mixes with the bloud \& helps to its fermentation, \& which are found in $\mathrm{y}^{\mathrm{e}}$ aer of lower regions, or else because the pressure of the aier being lessend by the height of $y^{\mathrm{e}}$ place, it is scarce sufficient to lift up $\mathrm{y}^{\mathrm{e}}$ lungs \& soe respiration is hindered JL. ${ }^{63}$

Locke had not decided on a final theory of respiration at this point, again contrasting the chymical explanation of salts in the air required for fermentation with the physical explanation of air pressure. When he copied this into his commonplace book, probably in 1664, he was more precise in his identification of the volatile salt, replacing the phrase "or other materiall parts" and citing a new source of support: "which by Mr Hooke are thought to be Niter" ${ }^{64}$ Locke now refined his initial supposition that some "salts" volatized the blood, suggesting instead that perhaps niter itself was responsible.

Both Hooke and Helmont believed the volatizing properties of salts in the air to be crucial to an understanding of respiration. Locke again used Boyle as an indirect reference to Helmont's writings on this point:

Chymici we have knowne such changes (seemingly chymicall) made in some saline concretes, by $\mathrm{y}^{\mathrm{e}}$ help chiefly of $y^{\mathrm{e}}$ volatising operations of $\mathrm{y}^{\mathrm{e}}$ open ayer, $\mathrm{y}^{\mathrm{t}}$ very few save those $\mathrm{y}^{\mathrm{t}}$ have attentively considered $\mathrm{w}^{\mathrm{t}}$ Helmont \& one or two other artists, have hintd on $\mathrm{y}^{\mathrm{t}}$ subject or have made triall of $\mathrm{y}^{\mathrm{t}}$ natur themselves will be apt to imagine Boyl Physiol. Essay: p127. $61 .^{65}$

\footnotetext{
${ }^{59}$ Ibid., p. 225.

${ }^{60}$ Boyle, op. cit., note 29 above, vol. 2, p. 302.

${ }^{61}$ Bodl. MS Locke f.19, p. 226, cf.

Boyle, op. cit., note 29 above, vol. 2,

pp. 314-15.

${ }^{62}$ Bodl. MS Locke f.19, p. 226.

${ }^{63}$ Bodl. MS Locke f. 27, pp. 168-7 rev. (under the heading "64").
}

\footnotetext{
${ }^{64}$ Bodl. MS Locke f.19, p. 158. In this commonplace book, the note was succeeded by that from Lower on "Opening" each side of a dog, almost certainly in 1664 .

${ }^{65}$ Bodl. MS Locke f.27, pp. 156-7 rev. (under the heading "Q.65"). Not previously published. Cf. Bodl. MS Locke d.9, p. 90, under the heading "Volatizatio". Cf. Boyle, op. cit., note 29 above, vol. 2, p. 107.
} 


\section{Jonathan Walmsley}

Locke was clearly moving towards the supposition that the air volatized the blood-the question was how this volatization took place - through mixing with the air, or fermenting in it. Further investigation with Lower provided more direct evidence of the processes at work:

Sanguis Bloud taken out of $\mathrm{y}^{\mathrm{e}}$ veines and arteries of $\mathrm{y}^{\mathrm{e}}$ same creature at $\mathrm{y}^{\mathrm{e}}$ same time very much differs. $\mathrm{y}^{\mathrm{t}} \mathrm{y}^{\mathrm{t}}$ comes out of an opend veine being $\mathrm{y}^{\mathrm{e}}$ greatst part of it of a darke colour $\mathrm{w}^{\mathrm{c}}$ they commonly call crassamentum nigrum with a florid red about $\mathrm{y}^{\mathrm{e}}$ thicknesse of half a crowne on $\mathrm{y}^{\mathrm{e}}$ top. $\mathrm{y}^{\mathrm{t}} \mathrm{w}^{\mathrm{c}}$ comes out of an opend atrerie is all of $\mathrm{y}^{\mathrm{t}}$ florid colour without any Crassamentum nigrum R. Lower. ${ }^{66}$

The general statement, however, was subject to one exception:

Sanguis Bloud taken out of $\mathrm{y}^{\mathrm{e}}$ artery of $\mathrm{y}^{\mathrm{e}}$ lungs hath its crassamentum nigrum like $\mathrm{y}^{\mathrm{t}}$ which comes out of $y^{e}$ vains soe $y^{t} y^{e}$ red florid bloud is made only in $y^{e}$ left ventricle of $y^{e}$ heart RL w ${ }^{\text {ch }}$ perhaps is by $\mathrm{y}^{\mathrm{e}}$ mixture of $\mathrm{y}^{\mathrm{e}}$ aire with it $\mathrm{w}^{\mathrm{ch}}$ gives it volatilization \& colour. ${ }^{67}$

Locke followed Lower's error in supposing that the blood going from the lungs to the heart was of the same sort as venous blood. This suggested that the lungs drew the air into the blood which was then transported to the heart and there made volatile in the left ventricle. ${ }^{68}$

In addition, rather than quoting Helmontian experimental results at second hand, Locke began directly to reference Helmont's work on these points:

Sal Volatile Helmont Blas humanum n.35.p.150.52 where he says $\mathrm{y}^{\mathrm{t}} \mathrm{y}^{\mathrm{e}}$ aire makes $\mathrm{y}^{\mathrm{t}}$ all $\mathrm{y}^{\mathrm{e}}$ bloud transpires \& becomes volatile, but being distild leaves a caput mortum ${ }^{69}$ But $y^{t}$ he says $n 45$ that $y^{\mathrm{e}}$ aier volatizing $\mathrm{y}^{\mathrm{e}}$ sulphur of any concrete, all $\mathrm{y}^{\mathrm{e}}$ alkali will become a volatile salt. Q How $\mathrm{y}^{\mathrm{e}}$ aier may be soe applyd as to effect this whither by expressing to it or fermenting in it. JL. ${ }^{70}$

A working hypothesis of the process in place, there remained the question of the purpose of respiration-why did the blood need to be volatized? Reflections on notes from Willis's lectures provided an inspiration. Willis had supposed that both venous and arterial blood were responsible for the body's nutrition. ${ }^{71}$ Locke's understanding of the chymical processes involved in respiration allowed him to refine this theory:

Nutrition seems only to be produced by the arterial blood, because the heart uses the artery associated with the heart and artery associated with the lungs to make blood hasten away from the left ventricle. JL. ${ }^{72}$

${ }^{66}$ Bodl. MS Locke f.19, pp. 212-13.

${ }^{67}$ Ibid., p. 226. This note immediately followed that titled "Sal Volatile" concerning the creation of volatility from fermentation, salts and air noted above.

${ }^{68}$ Locke's interest in the role of fermentation in volatization is shown by the fact that he followed the note on "Sanguis" with an extract from Martin Kerger's De fermentatione (Wittenberg, J Borckard for Heirs of T Moevius \& E Schumacher, 1663) under the heading "Fermentatio" (Bodl. MS Locke f.19, p. 226). In Locke's system, entries were ordered according to the first letter and first successive vowel. Adding "Fermentatio" under the "Sa" heading was quite out of order. Cf. Milton, op. cit., note 7 above.

\footnotetext{
${ }^{69}$ Locke here used an alchemical symbol to indicate the phrase. Literally "death's head", "caput mortuum" denotes the residue after a chymical operation such as a distillation or sublimation; anything from which all that made it valuable has been removed.

${ }^{70}$ Bodl. MS Locke f.19, pp. 226-7. Not previously published.

${ }^{71}$ Willis, op. cit., note 48 above, pp. 61-5, cf. Bodl. MS Locke f.19, pp. 18-22.

${ }^{72}$ Bodl. MS Locke f.19, p. 232: "Nutritionem solum fieri a sanguine arterioso videtur, quia cor arteriam coronariam et pulmones arteriam a sinistro ventriculo sanguinem devolantem habet. JL". Not previously published.
} 


\section{John Locke on Respiration}

Air was drawn in as a source of nutrition to be volatized in the heart and carried to the body by the arterial blood. Locke now felt himself to be in a position to ascribe an overall purpose to respiration:

Sanguis Aer probably it is $\mathrm{y}^{\mathrm{e}}$ nitrous salt in $\mathrm{y}^{\mathrm{e}}$ aier $\mathrm{y}^{\mathrm{t}}$ gives it this tincture \& volatizes it, \& $\mathrm{y}^{\mathrm{e}}$ volatile part in circulation being either transmuted into nourishm ${ }^{\mathrm{t}}$ of $\mathrm{y}^{\mathrm{e}}$ part, $\mathrm{y}^{\mathrm{e}}$ remaining bloud in $\mathrm{y}^{\mathrm{e}}$ vains is lesse spirituosus \& both in colour \& consistence comes nearer a caput mortuum, \& therefor is returnd by $\mathrm{y}^{\mathrm{e}}$ vains to $\mathrm{y}^{\mathrm{e}}$ lungues \& heart to be new volatilizd \& soe by succession is

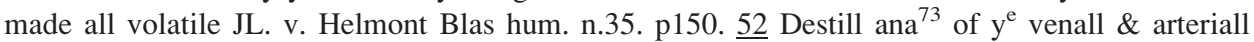
bloud of an animall \& try whether they will yeild different quantitys of Salt. JL. ${ }^{74}$

Air volatized the blood to provide nourishment for the body. Once the body consumed the volatile part of the blood, it was sent back to the lungs and heart to be volatized again to provide a continuous supply of bodily sustenance. Locke even suggested a test for this theory-ascertain whether the venous and arterial blood have different levels of salt to indicate their different levels of volatility. Locke's theory explained the difference between the venous and arterial blood and provided an explanation as to why the blood circulated in the first place. Locke again leant upon Helmont to formulate and substantiate his theories concerning the nature and purpose of respiration.

In January 1665 Hooke published his Micrographia, where, regarding the "charring of Coals", he concluded that:

the dissolution of sulphureous bodies is made by a substance inherent, and mixt with the Air, that is like, if not the very same, with that which is fixt in Salt-peter, which by multitudes of Experiments that may be made with Saltpeter, will, I think, most evidently be demonstrated. ${ }^{75}$

Locke could now quote Hooke's published experimental findings as a foundation for his own hypotheses:

Sal volatile It seems probable $\mathrm{y}^{\mathrm{t}} \mathrm{y}^{\mathrm{e}}$ aier volatilizes bodys \& takes away theire sulphur by some nitrous particles v. Zwelpher pharmac. p782. $\underline{53}$ Hookes microgr: c16 p103. $\underline{65}$ Helmont p151. It seems that the colder the air, the more suited it is for making something volatile and the northern wind more than the south-western wind. Query does fire by this kind of air burn sharper and consume kindling faster? JL v. Helmont ib n56. ${ }^{76}$

Locke cited and agreed with Helmont's assertion that cold air was more suited to making the blood volatile. ${ }^{77}$ The experimental findings of Helmont and Hooke supported Locke's assertion that the air contained nitrous particles and that these were the active agents of

\footnotetext{
73 “An equal quantity or number" in Oxford English Dictionary, Oxford University Press, 1961, vol. 1, p. 299.

${ }^{74}$ Bodl. MS Locke f.19, p. 227. Not previously published in full.

${ }^{75}$ Robert Hooke, Micrographia: or, Some physiological descriptions of minute bodies made by magnifying glasses, London, Martyn and Allestry, 1665 , p. 103.

76 “"Aer vero quanto frigidior tanto alicujus rei volatilizatione aptior videtur \& Boreas Austro. Q an
}

non ab hujusmodi aere acrior ardeat ignis \& citius fomitum consumat?" Bodl. MS Locke f.19, pp. 227, 272. Not previously published in full.

${ }^{77}$ Helmont, op. cit., note 23 above, p. 187: "But I blame the air, which as oft as it is colder, is also nearer to its own natural quality, and a more potent seperater of the waters: And so, by how much the air is colder, it doth the more volatilize the venal bloud into a Gas". 


\section{Jonathan Walmsley}

volatization. He outlined a further experiment to determine the truth of his chymical hypothesis, again citing Hooke to support his conjectures:

Respiratio laesa $\mathrm{Q}$ whether there be not something in ye aier $\mathrm{y}^{\mathrm{t}}$ in respiration ascends $\mathrm{y}^{\mathrm{e}}$ bloud in $\mathrm{y}^{\mathrm{e}}$ heart, after $\mathrm{y}^{\mathrm{e}}$ same manner $\mathrm{y}^{\mathrm{t}}$ it keeps in $\mathrm{y}^{\mathrm{e}}$ flame of a candle, since we finde in mines \& such other places where a candle will not burne a man cannot live. Q also whether it be niter as $\mathrm{M}^{\mathrm{r}}$ Hooke intimates in his micrographia. JL. Take a glasse of such a length, \& a mouth soe wide as will just let a kandle burne in it, out of $y^{\mathrm{e}}$ sides of this let there be 2 or more necks, so that at them 2 or more men may let the ayer that comes out of their lungs ( $\&$ soe is robd of its ascending spirits) into $\mathrm{y}^{\mathrm{e}}$ glasse where $\mathrm{y}^{\mathrm{e}}$ candle is \& see whether this will lessen $\mathrm{y}^{\mathrm{e}}$ flame or make it goe quite out. JL. ${ }^{78}$

Where others had connected fire and life, they had experimented only with an animal and a flame sharing the same air. ${ }^{79}$ Locke tried to forge a more direct connection-feed the flame with respired air-if the flame went out, the element it required must have already been consumed in respiration. It is also notable that Locke now considered the example of failing candles in mines to support the chymical theory, whereas previously he had supposed it supported Boyle's favoured explanation.

Locke was gradually tying together the elements of his research to formulate his own theory of respiration. In doing so he moved away from his first explanation in the 1664 note "Respiratio", the removal of "vapours". He moved towards a more sophisticated chymical theory where inspiration facilitated the extraction of something nitrous from the air and its transfer into the blood, which was then volatized by a ferment in the left ventricle of the heart. This volatized blood was then circulated to provide nourishment for the body. When the volatile nourishment was spent, the blood was returned to the lungs and heart to be volatized and circulated once again. This aerial agent was likely the same as that responsible for combustion. Locke had completely rejected the view that respiration served to cool the blood. He was now well on his way to a coherent theory of nature and purpose of respiration. However, a spell in diplomatic service intervened and he spent the latter part of 1665 and early 1666 on a mission to Cleves. ${ }^{80}$

\section{Lower's Vindicatio}

As Hooke's Micrographia was published, Lower was at work of a somewhat different nature. On 27 October 1664, Edmund Meara was given the imprimatur for his soon to be published Examen diatribae Thomae Willisii, an attack on the general research project at Oxford, and Willis in particular. ${ }^{81}$ Lower sought to defend the theories of his mentor in a hastily written and somewhat intemperate rejoinder, the Diatribae Thomae Willisii de

\footnotetext{
${ }^{78}$ Bodl. MS Locke d.9, p. 36. Not previously published.

${ }^{79}$ Hooke in January 1663 (Frank, op. cit., note 4 above, pp. 151-2). Ent in January 1665 (ibid., pp. 160-1).

${ }^{80}$ M Cranston, John Locke, London, Longmans, 1957, pp. 81-7.

${ }^{81}$ E Meara, Examen diatribae Thomae Willisii doctoris et professoris Oxoniensis de febribus,
}

\author{
London, J Flesher, 1665. Locke was aware of this \\ book (Bodl. MS Locke d.11, fol. 52v and Bodl. \\ MS Locke d.9, pp. 3, 36) and knew its author; \\ Meara had treated Locke's father during his final \\ illness (Corr., Letter 110, vol. 1, pp. 162-3, and \\ Letter 111, vol. 1, pp. 163-4). It is also probable that \\ Meara was the source of one of Locke's medical \\ recipes, headed "Dr Meara" (Bodl. MS Locke \\ c.29, fol. 4r).
}




\section{John Locke on Respiration}

febribus vindicatio. ${ }^{82}$ Given its imprimatur on 22 March 1664/5, the book gave Lower the occasion to outline his views on physiology. ${ }^{83}$ The work therefore provides a useful point of contemporary comparison with Locke's observations on the subject. In Lower's view the blood was set alight, or "ascended," by means of a nitrosulphurous ferment in the heart: in those [animals] whose blood contains a great deal of sulphur and highly inflammable particles, in its passage through the sinuses of the heart, it is strongly activated, rarefied, and as it were inflamed by the nitrosulphureous ferment within them. ${ }^{84}$

Lower felt that the ferment was present in both ventricles of the heart and that the ascension process began in the right ventricle, causing potential problems for the flame in the blood:

since the blood-mass, in going up into the right ventricle of the heart, is imbued with chyle still crude and fresh, it emits flames rather sparingly, like green wood, with smoke and sooty vapours ... ${ }^{85}$

The blood was then sent to the lungs so that it might get rid of the vapours that were in danger of extinguishing the vital flame:

passing out of the heart like a flame from ignited tinder, it at once seeks open vents, namely the lungs, by which not only the soot that could smother the freshly lit flame may be sent away, but also the blood, in passing through, may be impregnated by the nitrous food of the air. ${ }^{86}$

The role of the lungs was to impregnate the blood with a nitrous food for the body, an "aeris pabulum nitrosum", as well as to remove the waste products of the continually fermenting blood. While the blood may be free from the smoky vapours of the first "ascension" in the right ventricle and have the nitrous food it needs,

it is worth observing, and may be objected here, that blood drawn from the pulmonary vessels, veins and arteries alike, appears very much the same in either case, but neither is as red as the arterial blood in the rest of the body. ${ }^{87}$

Lower was again recording his belief that blood in the pulmonary vein was similar to arterial blood, but thought this quite consonant with his theory. The right ventricle began the process, but the left did most of the work:

it is in the left sinus that both the kindling and the mixture are mainly accomplished ... so that by this objection the difference of colour and consistency in the blood all the more obviously depends on the flamelet or ferment of the heart. ${ }^{88}$

The properly ascended blood was then sent out to transmit heat to the rest of the body. This heat was diminished by its circulation through the body and so had to be continually re-fermented. Lower neatly summed up his views on the purpose of respiration:

For these two uses the lungs, which are the vents of the burning blood, are equipped with a twofold movement; inspiration, by which the air is sent in, meets the boiling blood, cools it, and as some

\footnotetext{
${ }^{82} \mathrm{R}$ Lower, Diatribae Thomae Willisii de febribus vindicatio, adversus Edmundum de Meara, London, Martyn \& Allestry, 1665. Reprinted with translation in K Dewhurst, Richard Lower's Vindicatio: a defence of the experimental method, Oxford, Sandford Publications, 1983; hereafter Lower, Vindicatio. The dispute between Lower and Meara is
}

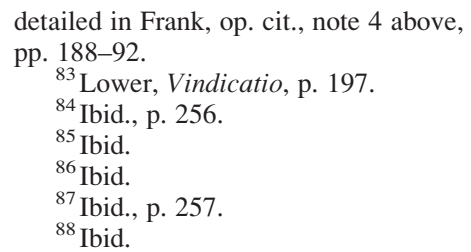




\section{Jonathan Walmsley}

think refreshes it with, so to speak, nitrous food; and expiration, by which the remains of that air are breathed out together with the vaporous effluvia from the blood. ${ }^{89}$

Both Locke and Lower supposed that a part of the air was a "food" used in respiration to volatize the blood, and both supposed that this was necessary for the preservation of life. Both also mentioned a nitrous element in the air as a candidate for this "food". Lower supposed a ferment in both ventricles of the heart whereas Locke focused solely upon the left. Consequently, Locke had not concentrated on the removal of "vapours" from semi-ascended blood, largely neglecting this aspect of respiration in his theorizing. Nor did Locke feel that the air was needed to cool the blood, where Lower still mentioned this traditional explanation. The two men were working closely together and were producing similar theories, but differences in outlook and experience were subtly colouring their preferred explanations.

\section{Air and Blood}

On returning to Oxford from his diplomatic trip abroad, Locke's association with Boyle picked up pace. During a trip to Somerset in the spring of 1666, Locke attempted to carry out experiments concerning air pressure in mines on Boyle's behalf. The wretched experimental report to Boyle is given in a letter of 5 May. ${ }^{90}$ Because the men had to climb into the mine at an angle, the miners would not allow Locke to carry Boyle's contraption down into it. A trip up a nearby hill only served to illustrate that Locke had not set up his apparatus correctly and that some air was still trapped in the tube designed to create a vacuum. ${ }^{91}$ The main purpose of the trip frustrated, Locke was still able to glean useful information from one Mr Buckland:

Aer In the gruffs of Minedeepe if by damps they swound, they draw them up dig a hole in $\mathrm{y}^{\mathrm{e}}$ earth \& lay in their faces \& soe cover them with the turfs as close as they can \& this recovers them. In deepe grufs they can not well breath unlesse fresh ayre be conveyed downe in a trunke by ye side of the gruff $\&$ turfs set up on $y^{\mathrm{e}}$ lee side of $\mathrm{y}^{\mathrm{e}}$ hole to convey in the aire, $\mathrm{w}^{\mathrm{ch}}$ turfs if turned on the other side or laid downe flat they below begin presently to faint $\&$ want breath, \& if they have carried downe a nosegay with them $\mathrm{y}^{\mathrm{e}}$ flowers that but now smelt sweet, will stinke like carrion immediately. They finde it dangerous to goe downe into a gruf that hath beene lately burnd if there be any remaines of the fire left in the cranys Mr Buckland. ${ }^{92}$

The parallel between this phenomenon and Boyle's own experiments will have been readily evident to both men.

Once settled back into Oxford, Locke had further time for medical studies. As well as returning to medical reading, Locke began chemical experimentation once again, this time directing his own research in partnership with two colleagues. ${ }^{93}$ Locke also began taking numerous detailed notes from Boyle on the preparation of chymicals. ${ }^{94}$ In his old chymical notebook, interspersed between notes from his course with Stahl, Locke recorded two new experiments on blood. ${ }^{95}$ In both cases Locke evaporated then distilled the blood under a

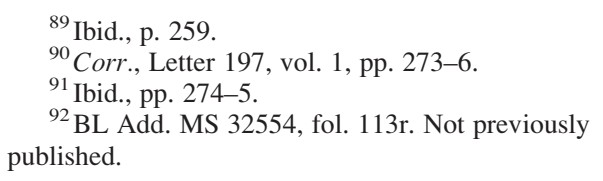

\footnotetext{
${ }^{93}$ Walmsley and Milton, op. cit., note 7 above, pp. 98-101.

${ }^{94}$ Bodl. MS Locke f.25, passim.

95 Dewhurst, 'Locke's contribution', op. cit., note 3 above, pp. 201-2, erroneously attributes Locke's
} 


\section{John Locke on Respiration}

high heat. In one case a salt was produced, ${ }^{96}$ but in the other no salt could be detected. ${ }^{97} \mathrm{We}$ have already seen that Locke believed such experiments might help to establish his view that blood contained a quantity of salt. These variable results doubtless frustrated any attempt to verify this conjecture. But they do show that Locke was not beyond putting some experimental effort behind his theoretical activities.

This interest in the chymical properties of the blood may explain the existence of a list of twenty-three headings in one of Locke's commonplace books, titled 'Tryall about the bloud espetially humane'. ${ }^{98}$ These headings comprised an agenda of enquiries to be made concerning the blood beginning with its chemical analysis, and including such things as its sensible qualities, its weight, and its reactivity with acids, alkalis and other volatile spirits. Similar lists would later appear in Boyle's manuscripts and his Memoirs for the natural history of humane blood, dedicated to Locke. ${ }^{99}$ For this reason, Boyle is often cited as the originator of this list. ${ }^{100}$ While there are some interesting similarities between this list and several Boyle manuscripts from the 1680s, the former differs from the latter in several ways. ${ }^{101}$ Firstly, Locke did not cite Boyle as author of the list, something he assiduously did elsewhere in his writings from this period. ${ }^{102}$ Secondly, the list in the Locke manuscript is of "tryalls" to be made, where Boyle generally referred to "titles" or "heads" of enquiry. The only extant list of "tryals" in the Boyle manuscripts related to this subject shares no common entries with the list in Locke's manuscript. Finally, there are significant differences in content between the list in Locke's commonplace book and those in the extant Boyle manuscripts. Of the twenty-three individual items in the former, the wording of just five closely matches entries in the six Boyle manuscripts related to this subject. ${ }^{103}$ There are nine items in the Locke manuscript that have no equivalent at all in the Boyle manuscripts. These contain some forty-seven topics that are not present in the Locke manuscript. Given these substantial differences and limited similarities, Locke's intense interest in this subject, his several experimental conjectures on related points, his practical experience in chymistry, and the lack of attribution to Boyle, it is probable that Locke formulated these queries, then shared them with his more renowned colleague-thereby inspiring the later variant lists and the book of which he was eventually the dedicatee.

notes on spirit and tincture of blood (BL MS Locke f.25, pp. 189,277$)$ to this period. These notes were derived from Locke's 1663 course with Stahl. The note on the tincture of blood is followed by a note on "Sal volatile" which used a single letter "M" to denote the month, characteristic of this first period of the notebook's use. See G G Meynell, 'Locke as a pupil of Peter Stahl', Locke Studies, 2001, 1: 221-7.

${ }^{96}$ BL MS Locke f.25, pp. 276, 342, cf. Dewhurst, 'Locke's contribution', op. cit., note 3 above, p. 202. Dewhurst failed to note that his transcription was a translation from the Latin and misattributes the note to p. 277.

${ }^{97}$ BL MS Locke f.25, p. 33, cf. Dewhurst,

'Locke's contribution', op. cit., note 3 above, p. 201.

${ }_{98}$ Bodl. MS Locke f.19, pp. 272-3, 302-3.

${ }^{99} \mathrm{R}$ Boyle, Memoirs for the natural history of humane blood, especially the spirit of that liquor, London, Samuel Smith, 1684.

\footnotetext{
${ }^{100}$ M Hunter and H Knight (eds), Unpublished material relating to Robert Boyle's Memoirs for the natural history of Human blood, University of London, Robert Boyle Project, 2005. See also Dewhurst, 'Locke's contribution', op. cit., note 3 above, on p. 201. Dewhurst mistakenly confines the list to Bodl. MS Locke f.19, pp. 272-3. P Anstey, 'Locke, Bacon and natural history', Early Sci. Med., 2002, 7: 65-92, on p. 81 re-states the supposed association and repeats Dewhurst's error of citation.

${ }^{101}$ See Hunter and Knight (eds), op. cit., note 100 above, table on pp. 33-50 for details of all related claims below.

${ }^{102}$ For example, "Mr Boyle's Scheme of Qualities $68 "$, in NA PRO $30 / 24 / 47 / 30$ fols. $21-23$, and numerous chymical notes in Bodl. MS Locke f.25.

${ }^{103}$ Hunter and Knight (eds), op. cit., note 100 above, table on pp. 33-50, items 3, 6, 11, 12 and 15 .
} 


\section{Jonathan Walmsley}

\section{'Respirationis usus'}

When Locke was promoted to the ranks of the theologi in 1665, in order to keep his place at college, he was obliged to take orders or switch to a faculty studentship. ${ }^{104}$ That he did not immediately do either and did not lose his place, suggests that he was well respected by the college hierarchy. Nonetheless, his position was precarious and a medical degree would render it secure by allowing him to move to the faculty studentship. A medical degree would require the submission of a disputation. This requirement may explain the existence of a draft disputation by Locke entitled 'Respirationis usus'. ${ }^{105}$ Drawing upon his recent experiences, including those from the Mendips, the paper cannot have been written before May 1666. By November 1666 Locke had given up hope of obtaining an MB by conventional means, ${ }^{106}$ placing the paper's likely composition between these dates.

The paper itself is composed of two parts, a number of prefatory remarks and the disputation proper. The remarks on the verso of the first leaf that precede the discussion of respiration show Locke trying a number of different titles, apparently unsure of which was most appropriate to his task. ${ }^{107}$ In all cases, however, these titles dealt with the dispute between chymists and Galenists. Locke posed three questions: whether chemical remedies should be preferred to those of the Galenists, whether there was a universal remedy, and whether opposites were cured by opposites. ${ }^{108}$ The first was affirmed, the latter two denied. It was not clear to whom the second question was posed-chymists and Galenists alike occasionally succumbed to the appeal of "panaceas". But it was Galenists alone who maintained that "opposites were cured by opposites", as Locke pointed out:

That contraries are cured by contraries is an axiom so well known and endorsed by the mouth of all that nothing is truly better known, that it had been hitherto accepted by almost the entire medical profession as if the foundation of all medical practice, established both by the agreement of the Ancients and by unchanging practice. ${ }^{109}$

Locke sided with the chymists, promising to refute this principle and then reveal the true method of healing. ${ }^{110}$ Apparently having second thoughts, Locke promptly abandoned these grandiose ambitions, left the rest of the page blank, started afresh on a new leaf and composed a disputation concerned solely with the purpose of respiration.

He opened his disputation with a direct attack on Galenic orthodoxy: "Would the primary purpose of respiration be to cool the blood? No". ${ }^{111}$ Prepared to agree that "nature

\footnotetext{
${ }^{104}$ The requirements of studentships are discussed by Milton, op. cit., note 1 above, pp. 29-31.

${ }^{105}$ NA PRO 30/24/47/2 fols. 71-74.

${ }^{106}$ On 3 November 1666, at Locke's request the Earl of Clarendon sent a letter to John Fell, Vice-Chancellor of the University, stating that Locke was "in all respects qualified for the degree of Doctor in that Faculty" (NA PRO 30/24/47/8A). This recommendation, practically a command, was ignored. Locke then found a more persuasive advocate. On 14 November 1666, the King required the Dean of Christ Church to "suffer him, the said John Locke, to hold and enjoy his Student's place in Christ Church, together with all rights, profits and emoluments thereunto belonging, without
}

taking holy orders" (NA PRO 30/24/47/22 fol. 9). Locke had drafted this letter himself (Bodl. MS Locke c.25, fol. 11).

${ }^{107}$ NA PRO 30/24/47/2 fol. 71v.

${ }^{108}$ Ibid.

${ }^{109}$ Ibid.: "contraria contrariis curari adeo notum et omnium ore iactatum axioma ut nihil notius adeo ut hactenus tanquam totius medecinae practicae fundamentum et veterum consensu et rerum usu stabilitum, ab universa paene asclepiadum familia receptum fuerit."

${ }^{110}$ Ibid.

${ }^{111}$ Ibid., fol. 73r: "An primarius respirationis usus sit refrigeratio cordis Negatur." 


\section{John Locke on Respiration}

seems to work greatly to this effect, that that vestal fire of our life is cherished", ${ }^{112}$ Locke did not think that the lungs cooled this internal flame: "would Nature not be a badly wasteful Matron if she aroused such great fires in us that it would be continually necessary for her to blow cold airs through us to prevent us from being burned up?"113 Locke held that life and animation were constituted by "animal spirits". ${ }^{114}$ These required volatization and "ascension" by the air, then to be transported around the body in the blood to keep all parts alive:

For seeing that it is upon this that animal life hinges, that there should be a continuous and constant provision of animal spirits, that is that the parts of the blood should be changed into a subtle and volatile material, which, when diffused everywhere throughout our arteries and nerves, imparts motion, feeling and heat to the body; which appears to be the fundamental reason and whole driving force of our life. ${ }^{115}$

Locke supported this theory with experimental results from chemistry. He first noted that air was "indispensable in order to both ferment and volatize things", ${ }^{116}$ returning to the connection made in some of his earliest chymical speculations on the subject. He then continued with more detailed experimental results:

And how impossible it would be in sealed vessels, into which air is prevented from flowing and from which ordinary air has been removed, for something by itself to satisfactorily become volatile and covered with flames, if even the fiercest fire will be applied. And that which burns easily in the open air and flies up into flames and smoke in being fully consumed, the same enclosed in glass vessels, you cannot reduce them further than the stage of cinders even when shaken by the highest degrees of fire. For the most part, they degenerate into "fixed bones" or a "caput mortuum". 117

Locke here returned to the conclusions of the second half of 1664 note "Respiratio", presenting the same experimental results in the same order.

Locke next considered the chymical processes at work, proposing a candidate for the active agent in the air:

If one can conjecture something in such obscurity, this sort of spirit has a highly volatile nitrous nature (not unskilled would be those who suspected they observed salt-peter), which seems to be the proper dissolver of sulphurous and inflammable bodies. ${ }^{118}$

\footnotetext{
${ }^{112}$ Ibid.: "in eo maxime laborare videtur natura, ut vestalis illa vitae nostrae foveatur ignis."

${ }^{113}$ Ibid., fol. $73 \mathrm{r} \& \mathrm{v}$ : "natura male prodiga esset materfamilias si tantos in nobis extruit focos ut continuo sibi necesse foret frigidum transpirare ne incenderentur aeres."

${ }^{114}$ Ibid.

${ }^{115}$ Ibid.: "cum enim eo in cardine versatur vita animalis, ut continuus constansque fiat provectus spirituum animalium, hoc es[t.] ut sanguinis partes in materiam subtilem et volatilem exaltentur quae cum per arterias nervosque undique diffusa corpori motum sensum et calorem impertiat in quo ipsa vitae nostrae ratio formalis vigorque totus consistere videtur."

${ }^{116}$ Ibid., fol. 72r: "necessarium sit aeiris interventus ad res et fermentandas, et volatizandas."
}

\footnotetext{
${ }^{117}$ Ibid.: "quamque impossibile sit in vasis clausis unde excluditur amovetur aeris communis aeris affluxus concreta per se satis volatilia et flammis opertuna, vehementissima licet ignis tortura volatilia reddere quaeque in aperto aere facile deflagrant et combusta tota in flammas aurasque evolant, eadem visceribus vitreis inclusa, et summis ignis gradibus vexata, vix in carbones nec ultra possis reducere. maxima parte, in ossam fixam sive caput mortuum degenerantur."

${ }^{118}$ Ibid.: "sit si quid in tanta obscuritate conjicire licet, naturae spiritum quondam nitrosum summe volatilem, qui non inepte suspicarentur observarent salem petrae corporum sulphureorum et inflammabilium esse menstruum appropriatum."
} 


\section{Jonathan Walmsley}

Locke now embraced Hooke's suggestion, sided with his contemporaries concerning the role that niter was suspected of playing in the generation of volatility, and subscribed to the chymical explanation for inhalation. He further conjectured that the sun's rays on the earth threw up these nitrous particles into the air which: "necessary to the conservation of our life and the volatility of our blood, we inhale and imbibe together with the air. Whence the little fire of our life is continuously inflamed in our heart." ${ }^{119}$ Locke had identified the end and means of the blood's volatization and, consequently, the purpose of respiration, thereby overturning the Galenic view:

This volatization is caused by fermentation and a kind of burning in the heart. But no kindling of this kind, be it fermentation or whatever we are permitted to call it, takes place without air itself. We conclude therefore that the air effectively kindles the heart's heat rather than cools it. ${ }^{120}$

For Locke, both heart and lungs played a role in respiration: the lungs drew the air into the blood, which was transferred to the heart, and there volatized by a "fermentation".

To support his theories, Locke referred to the miners' reports he had gathered in the Mendips that, irrespective of the air's temperature, without a continuous supply of fresh air, people would fall ill and die. ${ }^{121}$ Locke also recounted the counter-measures he had heard the men describe. ${ }^{122}$ They became ill because they were starved of the particles of air that were essential for life:

Because in fact a deficiency of food in the air, by which the heat of the heart must be kept warm and the mass of blood must ferment, the little flame of the heart, as if its kindling was taken away, is gradually extinguished. ${ }^{123}$

In Locke's 1664 note "Respiratio", the example of mines had been used as an instance of the theory that the air carried off foul vapours from the lungs - the air became saturated with vapours, could not carry off any more and caused fainting. In 'Respirationis usus', Locke thought rather that this example served to show that some part of the air was necessary for life. A similar treatment was given to the example of people fainting in crowded rooms. In 1664, Locke had supposed that the air became so saturated with the excrement that "it probably comes $\mathrm{y}^{\mathrm{t}}$ in crowds people swoune". ${ }^{124}$ He now held a different view:

The same thing often happens in meetings of men in any building previously enclosed, where frequently people who are weaker and of less solid make up suffer from fainting because ... the ferment of the enclosed air has largely been drawn out by so many dry lungs. ${ }^{125}$

\footnotetext{
${ }^{119}$ Ibid.: "quos ad vitam nostram conservandam sanguinemque nostrum volatizandum necessarios una cum aere haurimus et imbibimus, unde in corde accenditur continuo vitae igniculus."

${ }^{120}$ Ibid.: "volatizatio fit fermentatione et quasi accensione in corde, nulla autem huiusmodi fit accensio sive fermentatio sive quicquid aliud vocari libet nisi ipse aeris, concludimus igitur aerem efficientem fomitumque esse caloris cordis potius quam refrigerium."

${ }^{121}$ Ibid., fol. $72 \mathrm{v}$.

${ }^{122}$ Ibid.
}

\footnotetext{
${ }^{123}$ Ibid.: "quod vero pabuli aeri defectus quo calor cordis foveri et sanguinis massa fermentescere debet, cordis igniculum quasi subtracto fomite paulatim extinguit huic patet."

${ }^{124}$ BL Add. MS 32554, fol. 48r.

${ }^{125}$ NA PRO 30/24/47/2, fol. 72v: "Idem saepe evenit in hominum conventibus in aedificio quovis ante conclusis, ubi non raro debiliores et rarioris texturae homines deliquium patiuntur. aeris enim inclusi fermente a tot aridis pulmonibus magna ex parte exhausto."
} 


\section{John Locke on Respiration}

He no longer believed that these examples supported Boyle's theory. Locke did mention that air could become over-saturated by the breathing of people in an enclosed space:

... a very dense crowd of people shut in the same place, where there is no communication at all with external air, saturates the enclosed air by constant breathing, to such an extent that it makes the mass of the blood less suitable to be evaporated and dissolved and scarcely suffices for the burning of the little flame of the heart. ${ }^{126}$

Locke implies that something was apparently added to the air in the process of respiration to cause this "saturation", but it was not clear what he took this to be. Whatever his intended meaning concerning "saturation", Locke now clearly considered the expulsion of "vapours" to be, at best, a secondary function of respiration.

Locke next turned to objections to his theory: "how is it that, if the purpose of respiration is not to cool the heart, when heat has been increased, respiration increases also? ${ }^{127} \mathrm{He}$ noted that the heat of the heart only increased at those times when the blood circulated faster due to some exercise or a fever. His first account of the phenomena returned to a concern with the mechanics of respiration:

Thus the circular motion of the blood is increased. And it is necessary that respiration is increased at the same time; not towards cooling, but chiefly in order that the rushing blood is given freedom to move and pass through the lungs. For unless through the repeated admission of air the lungs were lifted and raised up, so to speak, the vessels compressed by the flabby lungs would hamper the flow of the blood from the right to the left ventricle of the heart. ${ }^{128}$

His second explanation touched on his more sophisticated conception that respiration provided nutrition for the body. If the blood circulated faster, and was depleted of vital spirits at a faster rate, blood without requisite spirits could be sent to the body. Respiration increased "so that no blood without that ferment, unprocessed, deathly and insufficiently suitable to nourishment and life, is sent to the brain and other offices of bodily function". ${ }^{129}$ In suggesting that respiration was a vital part of bodily nourishment, Locke found a reason to explain why, at times of bodily stress, the body needed to draw in more air. In positing the air as a true food for the body, Locke fashioned an important foundation of physiological theory. He also clearly distanced himself from the vestiges of Galenic tradition.

\footnotetext{
${ }^{126}$ Ibid., fol. 74r: "confertissima hominum turba in eundem locum conclusa ubi minus liberum est cum aere externo comercium aerem inclusum frequenti anhelitu saturat, adeo ut postea exaltandae solvendae sanguinis massae minus idonea, ad accendendam cordis flammulam vix sufficiat.",

${ }^{127}$ Ibid.: "si respirationis usus non sit cordis refrigorium, qui fit quod aucto interno calore augeatur et respiratio?"

${ }^{128}$ Ibid., fol. 74v: "Sanguinis igitur motus circularis ita auctus necesse est augeri simul respirationem non ad refrigerium, sed primo ut
}

properanti sanguini detur liber commeatus et per pulmones transitus, nisi enim: per repetitam aeris admissionem attollerentur ederenturque dictu pulmones, vasa flaccidis pulmonibus compressa cursum sanguinis a dextro ad sinistrum cordis ventriculum impedirent."

${ }^{129}$ Ibid.: "ut pro quantitate sanguinis cor et pulmones transeuntis debita fermenti aeri suppeditantur quantitates ne cruor sine isto fermento crudus cadaverosus et ad nutritionem vitamque parum idoneus ad cerebrum aliasque functionum officinas demitteretur." 


\section{Jonathan Walmsley}

\section{London}

At the beginning of April 1667, Locke left Oxford to take up residence in London with his new patron, Anthony Ashley Cooper, arriving mid-May. Despite his new responsibilities in the household, Locke still had time for medical researches. He soon became acquainted with the noted physician Thomas Sydenham, whose ground-breaking Methodus curandi febres he had recently read. ${ }^{130}$ Sydenham rejected the enquiry after natural causes and sought instead to apply a radically empirical approach to medicine, where therapy was determined solely by clinical effectiveness. Notes from Sydenham soon began to appear in Locke's notebooks. ${ }^{131}$ This new influence notwithstanding, Locke continued his work on respiration. For example, he proposed a vivisectional technique to ascertain whether the temperature of the air plays a role in respiration:

Respiration Query: Whether by cutting the windpipe of a live animal, and if the opening is joined to a vessel filled with hot air by means of a bound tube, if the hot air is regularly inhaled and exhaled, but the body of the dog is kept at the ambient temperature, Query, whether from strongly heated air it will become excessively heated or even die? JL. ${ }^{132}$

Locke was mostly likely seeking a practical means definitely to refute the Galenic claim that we respired to cool the blood. Locke also speculated as to whether air passed through the membrane of the lungs into the thorax:

Respiration Query: Whether air enters into the chest cavity by means of the lungs can be tested in this way: Make a wound in the chest, so that air can get in, and when the chest is full, close the wound. Then if something is breathed out by the mouth, it has of necessity passed through the membrane of the lungs. To this it can be objected that the pores in collapsed lungs are more contracted than those in inflated lungs. JL. ${ }^{133}$

The objection here is redolent of the point made in 'Respirationis usus' that the lungs when not inflated hindered the passage of the blood. The application of vivisection to the problem of respiration was the talk of the Royal Society at this time. Though Locke himself was not yet a member, Lower had been introduced to the society by Boyle on 2 May, his admission occasioning a flurry of activity within the Society on this topic. ${ }^{134}$ It is possible that Locke's notes were inspired by reports from Lower or Hooke on such

\footnotetext{
${ }^{130} \mathrm{~T}$ Sydenham, Methodus curandi febres, London, J Crook, 1666. Cf. Bodl. MS Locke d.11, fols. $79 \mathrm{v}, 268 \mathrm{r}-267 \mathrm{v}$ rev.

${ }^{131}$ See, for example, "Reumatismus" in Bodl. MS Locke f.19, p. 159.

${ }^{132}$ Bodl. MS Locke f.19, p. 159: “Respiratio Q an ex sectâ asperâ, arteriô in vivo animali et si alligato tubulo cujus oreficium aperiatur in vas aeri ferventi repletum. si aer iusto calidus inspiretur ex et tamen corpus canis in temperato ambiente servetur. Q an ex eo aere nimium incalescente laborabit vel extinguetur animal JL." This note immediately succeeded that from
}

\author{
Sydenham mentioned in note 131 above. \\ Not previously published. \\ ${ }^{133}$ Bodl MS Locke f.19, p. 338: “Respiratio Q \\ An aer ingrediatur cavitatem thoracis per pulmones \\ hoc modo experiri est. Vulnus inflige thoraci, ita \\ ut ingrediatur aer, repleto thorace claude vulnus. \\ Tunc si quid expiret per os, per pulmonum \\ membranam transire necesse est. huic objici \\ potest quod lapsorum pulmonum pori magis \\ arctantuntur quam expansorum JL." This note \\ immediately succeeded that concerning heated \\ air mentioned in note 132 above. \\ ${ }^{134}$ Frank, op. cit., note 4 above, p. 197.
}




\section{John Locke on Respiration}

discussions. For example, Locke again noted the result confirming the primacy of the diaphragm in the mechanics of respiration:

Respiratio If upon the cuting off $\mathrm{y}^{\mathrm{e}}$ nerves of the diaphragm, the cause of suddaine death be want of respiration, why cannot $\mathrm{y}^{\mathrm{e}}$ motion of the thorax supply that at least for a little time? JL unlesse $\mathrm{y}^{\mathrm{e}}$ loosenesse of the diaphragme hinder it. ${ }^{135}$

This result was well known to Locke-it was one of the first notes that he had made on the subject of respiration in conjunction with Lower. It seems rather more than coincidence that Locke returned to this particular finding when Lower was repeating the very same experiment for the information of the Royal Society. ${ }^{136}$

The activities of the Royal Society also occasioned an important change in Locke's views. The September 1667 edition of the Society's Philosophical Transactions furnished Locke with an intriguing new finding:

An Experiment of Signior Fracassati upon Bloud grown cold.

When any bloud is become cold in a dish, that part which is beneath the superficies appears much blacker, than that on top; and 'tis vulgarly said, that this black part of the bloud is Melancholy bloud, and men are wont to make use of this example to shew that the Melancholy humor as 'tis called, enters with the 3 others into the composition of the bloud. But Signior Fracassati maintains, that this blackish colour comes from hence, that the bloud, which is underneath, is not expos'd to the Air, and not from a mixture of Melancholy: to prove which he assures, that upon its being expos'd to the Air it changes colour, and becomes of a florid red.

An Experiment as easie to try, as 'tis curious. ${ }^{137}$

The Fracassati experiment indicated that it was exposure to air alone that rendered the blood florid. Locke read this report, immediately grasped its import and noted its implications: "If $y^{e}$ melancholy bloud exposed to $y^{e}$ aer turns florid (v. phil transact $p$ 493) it seemes to prove that the aire in breatheing mixes with $y^{\mathrm{e}}$ blood since the arteriall bloud in animals is much more florid then $\mathrm{y}^{\mathrm{e}}$ venall JL." ${ }^{138}$ Locke drew the conclusion that air directly volatizes the blood in the lungs, correcting Lower's error on this point. Indeed, this result would reshape Lower's thinking in the Tractatus de corde concerning the location of the volatization of the blood and cause him to place it exclusively in the lungs as the direct action of the air. ${ }^{139}$ Locke was at the forefront of physiological research. His instant grasp of the importance and implications of the Fracassati experiment put the final piece of the physiological puzzle in place. Locke had now formulated the basic elements, machinery and purpose of respiration, ahead of the publication of Lower's Tractatus.

\footnotetext{
${ }^{135}$ Bodl. MS Locke f.19, p. 338. This note immediately succeeded that concerning the entry of air into the thorax in note 133 above.

${ }^{136}$ Thomas Birch, History of the Royal Society of London, 4 vols, London, A Millar, 1756-1757, vol. 2, p. 200: "Octob. 17, The experiment ordered at the last meeting to be made at this was made accordingly by Dr. Lower, who by piercing both sides of a dog, and cutting two nerves passing towards the diaphragm, made the dog broken winded."
}

\footnotetext{
${ }^{137}$ Philosophical Transactions of the Royal Society of London, 1667, 27: 492. The experiment is discussed in Frank, op. cit., note 4 above, pp. 205-7.

${ }^{138}$ Bodl. MS Locke f.19, p. 303. It should be noted that the page Locke cited faces p. 493, explaining his erroneous pagination. Not previously published.

${ }^{139} \mathrm{R}$ Lower, Tractatus de corde. Item de motu \& colore sanguinis et chyli in eum transitu, London, J Redmayne for Jacob Allestry, 1669. Cf. Frank, op. cit., note 4 above, pp. 213-17.
} 


\section{Jonathan Walmsley}

Locke was able to piece together a sophisticated hypothesis, modify it in the light of experimental evidence, and arrive at substantial conclusions concerning the core of physiological theory.

\section{Locke's New Method}

Given this notable work, it is surprising that Locke soon rejected such theorizing. He began to work more and more closely with Sydenham, accompanying him on visits to patients, providing assistance with the text of the second edition of the Methodus, and appending a poem of fulsome praise to the work. ${ }^{140}$ Won over by Sydenham's methodology, Locke also wrote several papers in support of this new approach. In the 1668 'Anatomia' Locke decried the use of anatomical studies in the pursuit of medicine, citing researches into the lungs as examples of the futility of such endeavours:

whether respiration serve to coole the bloud, or give vent to its vapours, or to adde a ferm ${ }^{t}$ to it, or to pound \& mix its minute particles or whether any thing else is in dispute amongst the learned from whose controversys about it are like to arise rather more doubts then any cleare determination of the point \& all that anatomy has donne in this case as well as severall others is but to offer new conjectures \& fresh matter for endlesse disputations. ${ }^{141}$

Locke, who only a few months earlier had been at the forefront of physiological research, now distanced himself from the progress he and his contemporaries had made on this subject. Although Sydenham had an important influence on the practice of medicine, his views seem positively retrograde when applied to the physiological research of the time.

Indeed, this change in attitude on Locke's part was more or less permanent. Whilst Sydenham's outlook had a significant positive impact on the formulation of Locke's philosophical views, subsequent to his work with Sydenham, Locke never returned to serious research on respiration. He continued to read occasionally on the subject, as part of his general interest in the medical matters of the time, and there are a few notes scattered in his papers on the subject, but there is no further sustained consideration. Nonetheless, it is worth remarking that in these later notes, Locke reverted to the views of his Oxford days. Thus early in 1681, when discussing Jean de Hautefeuille's new book touching on the subject, sent to him by Nicolas Toinard, Locke repeated his opinion that air fosters the heat of the blood. ${ }^{142}$ Equally, Journal notes from 1683 on a "Traité des Fièvres" rejected the view that people feel hotter in fevers because the circulation is slower. ${ }^{143}$ Despite his new

\footnotetext{
${ }^{140}$ Letter from Thomas Sydenham to Robert Boyle, 2 Apr. 1668, in K Dewhurst (ed.), Thomas Sydenham (1624-1689): his life and original writings, London, Wellcome Historical Medical Library, 1966, p. 163; for the Methodus, see G G Meynell, 'Sydenham, Locke and Sydenham's De peste sive febre pestilentiali', Med. Hist., 1993, 37: 330-2; for the poem, see Sydenham, Methodus curandi febres, ed. G G Meynell, Folkestone, Winterdown Books, 1987, pp. 12-14. Translated from the Latin in ibid., pp. 227-8.
}

${ }^{141}$ NA PRO 30/24/72/2 fol.33v, cf. Dewhurst (ed.), op. cit., note 140 above, p. 88

142 Jean de Hautefeuille, L'Art de respirer sous l'eau et le moyen d'entretenir la flamme enfermée dans un petit lieu, Paris, 1681, H\&L, item 1402; letter from John Locke to Nicolas Toinard, 20 Feb. 1681, Corr., Letter 626, vol. 2, p. 379. Cf. the English translation in Dewhurst, John Locke, op. cit., note 3 above, p. 159.

${ }^{143}$ Journal, Monday, 26 Feb. 1683, cf. Dewhurst, John Locke, op. cit., note 3 above, p. 215. 


\section{John Locke on Respiration}

methodological outlook, Locke's own avowed agnosticism about unobservable natural processes could never unseat what experiment, chymistry and his own theorizing had compelled him to believe.

\section{Conclusion}

If Locke was not one of the leading physiological researchers of his day, he certainly worked very closely with them-helping both Lower and Boyle pursue their experimental programmes. Moreover, his own thinking on this subject, carefully recorded in his notebooks, is a detailed and vivid vignette of the progress made on some of the core parts of physiological theory. He was not a front-rank experimenter, lacking the temperament of Hooke, Boyle or Lower, and there are relatively few practical reports in his notes. Nonetheless, he was a sophisticated natural philosopher, steeped in the experimental results of his contemporaries, independent of mind and confident in imagination. Moreover, he formulated experimental scenarios designed to test his theories. Had he published a short summary of his thinking on respiration in late 1667 or early 1668, it might well have secured him a small but noteworthy place in the history of medicine as a theorist at the cutting-edge of contemporary research.

His work is also a portrait of the influence of the "chymists" on seventeenth-century medicine. Historians of philosophy and science portray Locke as a committed mechanist throughout his career. This characterization is too simple. The "chymical" movement in medicine had considerable momentum, and strongly attracted several of Locke's contemporaries. As his interests shifted from the mechanics of breathing, towards the purpose of respiration, so the references to chymistry increased and Locke's views began to change, leaning more and more to the theory that the air contained chymically active elements. Locke repeatedly cited Helmont as a foundation for his thinking and turned towards the chymical concept of "fermentation", expounded by Helmont, Willis and Lower. Equally, Willis's notes on nutrition provided an inspiration for Locke's mature view of respiration as a means to bodily sustenance. 'Respirationis usus' is strongly Helmontian in outlookLocke was definitely drawn towards an adherence to chymical theory. Locke's association with Lower, Willis's assistant and defender, appears to have played an important role in shaping the direction of Locke's thinking on this point. Yet despite their closeness, Locke had the confidence to formulate his own views, dismissing Galenic cooling, where Lower appears to have been rather more sympathetic.

Locke's relationship to Boyle is equally complex. Doubtless Boyle was a close colleague and an inspiration for several aspects of Locke's researches. Locke was well aware of Boyle's published work and used it to furnish several experimental examples. But Boyle's influence on the development of Locke's detailed views on this subject appears to have diminished over time. Locke never seems to have adopted the opinions of his more experienced colleague outright and, comparing the earlier and later work in Oxford, it is plain that Locke was gradually moving away from Boyle's views on respiration, as he was in other medical matters. ${ }^{144}$ Indeed, many of the citations of Boyle's works on this

\footnotetext{
${ }^{144}$ See Walmsley, op. cit., note 11 above.
} 


\section{Jonathan Walmsley}

subject were in fact indirect references to Helmont's findings. The marginal nature of Boyle's influence is highlighted by the dramatic shift that Sydenham prompted in Locke's natural philosophical outlook - transforming Locke into a radical empiricist at odds with the approach of his Oxford colleagues. Locke is usually depicted as Boyle's dutiful acolyte in this period-a junior partner who sat, unquestioning, at the feet of his master. This picture, put forward by numerous historians of science and philosophy, does not stand scrutiny. Locke's work on respiration, though only a small part of his career, shows that he pursued his own intellectual agenda with independence, intelligence and vigour. 